\title{
GLOBALIZACJA W ROSYJSKIEJ MYŚLI PRAWOSŁAWNEJ
}

Rosyjska Cerkiew Prawosławna oficjalnie niejednokrotnie wypowiadała się na temat globalizacji. Jej stanowisko opublikowane zostało w Podstawach społecznej doktryny RPC $C^{1}$. Podczas synodu w 7 III 2000 r. przyjęto postanowienie o odbyciu rozmów z władzą państwową na temat przeciwdziałania temu zjawisku. Główne tezy stanowiska Cerkwi mówią o zagrożeniach w dziedzinach:

1. unifikacji kultury,

2. wolności obiegu informacji,

3. wolności narodów.

Obrona tych sfer wymaga współpracy Cerkwi z państwem, organizacjami społecznymi oraz stowarzyszeniami o charakterze międzynarodowym. W dokumentach i wypowiedziach wymienia się kłamstwa, na których zbudowana została ideologia globalizacji:

1. o nastaniu nowych czasów - końcu historii, panowaniu nowego porządku światowego,

2. o powstaniu uniwersalnego społeczeństwa kierowanego przez jedno polityczne centrum,

3. o nieuniknionym charakterze globalizacji,

Prof. dr hab. HANnA KowAlSKA-STUS - kierownik Katedry Kultury Bizantyńsko-Prawosławnej w Instytucie Rosji i Europy Wschodniej Uniwersytetu Jagiellońskiego; e-mail: kowalska.hanna@gmail.com

${ }^{1}$ Основы социальной кониепции русской православной церкви, http://www.patriarchia .ru/db/print/141422.html (dostęp: 21.102015). 
4. o równych prawach i dostępie do dobrobytu wszystkich narodów i państw.

Rosyjski patriarchat reprezentuje określony pogląd na takie zagadnienia współczesnego świata, jak: ekonomiczna, kulturowa i informacyjna globalizacja, rozwój prawa międzynarodowego czy zjednoczenie Europy. Według opinii Soboru Rosyjskiej Cerkwi Prawosławnej globalizacja zagraża utracie duchowej, kulturowej, prawnej i ekonomicznej tożsamości narodów. Cerkiew nawołuje więc narody i sprawujących władzę do daleko posuniętej ostrożności przy wchodzeniu we wszelakie ponadnarodowe struktury. Postuluje także potrzebę wszechstronnej kontroli ponadpaństwowych korporacji.

Protojeriej Wsiewołod (Czaplin), wiceprzewodniczący Komisji Patriarchatu Moskiewskiego do spraw Kontaktów z Zagranicą, gdy wypowiadał się na temat globalizacji, rozróżniał pojęcia globalizacja i globalizm² ${ }^{2}$ Globalizację definiował jako system organizacji sterujących światową ekonomią (Międzynarodowy Fundusz Walutowy, Bank Światowy, Międzynarodowa Organizacja Handlu, ekonomiczne struktury Unii Europejskiej), który ułatwia transgraniczny i transoceaniczny obieg towarów i pieniędzy. Zalicza do tego także system kapitału światowego, który generuje zyski nie dzięki wytwórczości, lecz poprzez elektroniczno-giełdowe spekulacje. Transport i elektroniczne środki komunikowania wspomagają ten system. Wymienione organizacje wymuszają na państwach restrukturyzację ekonomiczną, narzucając metody jej przeprowadzenia i doprowadzając ich gospodarki do upadku. Z kolei organizacje międzynarodowe o charakterze politycznym, takie jak ONZ, OBWE czy Rada Europy służą do tworzenia globalnego systemu prawnego. Odpowiedzialność prawna w systemie ponadpaństwowym grozi sankcjami politycznymi, ekonomicznymi oraz interwencją zbrojną. Zdolność do obrony wewnętrznego systemu prawnego danego państwa jest wprost proporcjonalna do znaczenia, jakie ma ono w międzynarodowych organizacjach. Globalizm zaś definiowany jest przez protojerieja jako ideologia, która towarzyszy tym procesom.

Nadrzędnym problemem Europy w opinii rosyjskich hierarchów jest poszerzenie Unii Europejskiej, reprezentującej liberalny model cywilizacyjny, którego nie tworzyły nowo przyjmowane narody. Cywilizacja zachodnioeuropejska postrzegana jest przez Cerkiew rosyjską jako monoideologiczna i panująca na obszarze wielokulturowym. Powołując się na historyczne doświadczenie Związku Radzieckiego, stwierdzają oni, że organizm o takich cechach jest

\footnotetext{
${ }^{2}$ ПРОТОИЕРЕЙ ВСЕВОЛОД (ЧАПлин), Глобализачия и глобализм. Новые угрозы, «Время» 2003, nr 1, s. 11-37.
} 
niewydolny i ma znamiona totalitaryzmu. Globalizacja sprawia, że problem ten rozprzestrzenia się na cały świat, gdzie miliardy ludzi przyuczane są do akceptowania obcego modelu człowieczeństwa. Jak podkreślał ówczesny metropolita Kiriłł, przewodniczący Komisji Patriarchatu Moskiewskiego do spraw Kontaktów z Zagranicą, a dziś patriarcha, wyróżniającą cechą cywilizacji prawosławnej są: priorytet wartości duchowych nad materialnymi, dobra wspólnego nad indywidualnym, gotowość do ponoszenia ofiar, skłonność do samoograniczenia, przedkładanie wierności Prawdzie i ideałom nad dobrobyt ${ }^{3}$.

Metropolita Kiryłł stwierdza, że sytuacja jest poważna i wymaga odejścia od nic nieznaczących deklaracji o poszanowaniu innych kultur i wprowadzenia odpowiednich zmian w prawie i rządzeniu organizacji o charakterze światowym. Należy sprawić, by prawo międzynarodowe, podporządkowane liberalnym standardom, nie dominowało nad prawodawstwem państwowym, w odniesieniu do takich dziedzin, jak: stosunki państwa i Kościoła, oświata, kultura, etyka osobista, rodzinna i społeczna. Tradycje partykularne nie mogą znaleźć się w pozycji podrzędnej.

Globalizacja stanowi przedmiot analizy i krytycznej interpretacji wszystkich Kościołów i religii. W łonie chrześcijaństwa możemy zauważyć różne podejścia do tego problemu. Katolicką globalistykę rozpoczyna encyklika Pacem in terris (1963) Jana XXIII, skierowana do wszystkich ludzi dobrej woli. Miała ona na celu doprowadzenie do likwidacji broni masowego rażenia. Encyklika Populorum progressio (1967) Pawła VI po raz pierwszy w kościelnym dokumencie tej rangi zwracała szerzej uwagę na problem rozwoju. Encykliki Jana Pawła II Redemptor hominis (1979) i Solicitudo rei socialis (1987) postulowały nowy, chrześcijański humanizm, zaszczepienie wyższych duchowych wartości, odejście od cywilizacji śmierci w kierunku cywilizacji miłości. Proponowane odrodzenie chrześcijańskiego ładu w Europie miało opierać się na moralnym i intelektualnym potencjale Kościoła.

Jan Paweł II podkreślał pierwszeństwo wiary przed rozumem i etyki przed nauką. Papież prowadził dialog na ten temat $\mathrm{z}$ innymi konfesjami, marksistami, ateistami, wychodząc z założenia, że doprowadzi on do pozytywnych rozwiązań, pragnął zbudować pomost solidarności międzyludzkiej, opierając

\footnotetext{
${ }^{3}$ МИтРОПОЛИТ СМОЛЕНСКИЙ и КАЛИНИНГРАДСКИЙ КиРИЛЛ, Мировая интеграция и иивилизационное многообразие человечества, tamże, 2002, $\mathrm{nr} 4$, s. 7.
} 
się na płaszczyźnie moralnej ${ }^{4}$. Dużo uwagi poświęcał też globalnemu kryzysowi demograficznemu i ekologicznemu.

Zawarty w encyklice Jana Pawła II obraz radykalnie podzielonego świata, w odróżnieniu od optymistycznej diagnozy Pawła VI traktowano jako „panoramę klęski". Jako lekarstwo na ten stan Jan Paweł II wskazywał - nie bez impulsu płynącego wówczas z jego rodzinnego kraju - rozwój solidarności. Obraz świata, w którym pełni swą posługę Benedykt XVI, zwłaszcza po wydarzeniach 1989 r., jest już zupełnie inny, nie respektujący jednak wskazań o solidarności Jana Pawła II. Benedykt XVI w encyklice Caritas in veritate (2009) jako główne zadanie w zglobalizowanym świecie dostrzega odkrywanie owej Prawdy, która objawiona została w osobie Jezusa Chrystusa, i wyprowadzenie z niej wniosków dla rozwiązywania konkretnych wyzwań w życiu społecznym. Benedykt XVI koncentruje się przede wszystkim na problematyce globalizacji rozumianej jako łączenie się i wzajemne przenikanie rozmaitych systemów gospodarczych, społecznych, kulturowych i politycznych w skali całego świata. To ona bowiem, a nie trwający obecnie światowy kryzys owoc jej niewłaściwego kształtowania - jest dziś zasadniczym znakiem czasu wymagającym od Kościoła pogłębionej refleksji. Globalizacja nierzadko bywa dziś dla konserwatywnych architektów i komentatorów współczesnego świata swego rodzaju „straszakiem” jako źródło wszelkiego zła i niebezpieczeństw zagrażających współcześnie człowiekowi. W rzeczywistości jednak globalizacja nie jest zagrożeniem, lecz po prostu kolejnym współczesnym wyzwaniem, nie ma być zatem źródłem strachu, ale odpowiedzialnej postawy w jej kształtowaniu dla dobra człowieka. „Miłość w prawdzie stawia człowieka wobec zadziwiającego doświadczenia daru. Bezinteresowność jest obecna w jego życiu $\mathrm{w}$ rozlicznych formach, często nie uznawanych $\mathrm{z}$ powodu wyłącznie produktywistycznej i utylitarystycznej wizji życia. Istota ludzka została uczyniona dla daru, który ją wyraża i urzeczywistnia jej wymiar transcendentny. Czasem człowiek współczesny jest mylnie przekonany, że jest jedynym sprawcą samego siebie, swojego życia i społeczeństwa. Oto mniemanie, będące konsekwencją egoistycznego zamknięcia się w sobie"- pisze Benedykt XVI".

Papież Franciszek powrócił do postulatów solidarnościowych Jana Pawła II. Podczas swej pierwszej wizyty na Lampeduzie (8 VII 2013 r.) powiedział:

\footnotetext{
${ }^{4}$ Rosyjska interpretacja tego zagadnienia por.: Г. КругловА, Католическая глобалистика, „Свободная мысль” 2012, nr 3-4, Июнь, s. 106-112.

${ }^{5}$ http://info.wiara.pl/files_upload/09/07/07/961131_Caritasinveritate.pdf (dostęp: 10.01.2015).
} 
Straciliśmy poczucie braterskiej odpowiedzialności. Popadliśmy w obłudną postawę kapłana i sługi ołtarza, o których mówił Jezus w przypowieści o miłosiernym Samarytaninie: patrzymy na brata wpół umarłego na skraju drogi, myślimy może: „Ale to biedaczek" i idziemy dalej, to nie nasze zadanie. Uważamy, że jesteśmy w porządku i tym się uspokajamy. To kultura dobrobytu prowadzi nas do myślenia o sobie samych, znieczula nas na wołanie innych. Sprawia, że żyjemy w mydlanych bańkach, które są ładne, ale są niczym, są złudzeniem tego, co próżne, tymczasowe, co prowadzi do obojętności na innych, co więcej, do globalizacji obojętności ${ }^{6}$.

To sformułowanie - „globalizacja obojętności” - świadczy o zwróceniu przez papieża Franciszka uwagi na inne skutki zglobalizowanej polityki światowej, na pogłębiające się dysproporcje, wbrew zapowiedziom ideologów globalizacji, którzy wieszczyli wyrównanie poziomów cywilizacyjnych, kulturowych, ekonomicznych itd. „We współczesnej gospodarce trzeba wziąc inicjatywę we własne ręce, ponieważ aktualny system gospodarczy chce wszystko ujednolicić i podporządkować władzy pieniądza. System ten prowadzi do globalizacji, która nie jest dobra" - powiedział papież w wideoprzesłaniu do uczestników Festiwalu Katolickiej Nauki Społecznej w Weronie w listopadzie 2014 r. ${ }^{7}$

Współcześnie, kiedy większości państw istnieje oficjalny rozdział Kościoła od państwa, on w swojej nauce społecznej nie jest ukierunkowany ani przeciwko interesom państwa, ani zgodnie z nimi. Nie angażuje się bezpośrednio w działania ekonomiczne bądź polityczne na arenie społecznej, jak to było jeszcze przed I wojną światową. Kościół rzymskokatolicki wyznacza przede wszystkim cele moralne zgodne $\mathrm{z}$ doktryną chrześcijańską ${ }^{8}$. Nauka społeczna

\footnotetext{
${ }^{6} \mathrm{http} / / /$ pl.radiovaticana.va/news/2013/07/08/papie\%C5\%BC_franciszek_na_lampedusie (dostęp: 10.01 .2015$)$.

${ }^{7}$ http://pl.radiovaticana.va/news/2014/11/20 (dostęp: 10.01.2015).

${ }^{8}$ Patrick de Laubier wyodrębnił następujące etapy rozwoju społecznej nauki Kościoła Katolickiego: „I этап (христианство -гонимая религия) приходится на эпоху зарождения христианства - первые века нашей эры (до 313 года); II этап (постепенное превращение христианства в государственную религию) длится приблизительно с 313 года (издание Константином и Лицинием Миланского эдикта, узаконившего исповедание христианской религии в Римской империи) до начала средневековья; III этап (средневековый расцвет христианства) занимает весьма длительный период Средних веков, вплоть до Эпохи Возрождения (XIV век); IV этап (Реннесанс и Реформация) связан с Эпохой Возрождения (начиная с XIV века) и зарождением протестантизма (XVI век); V этап (эпоха буржуазных преобразованиий) период буржуазных революций (XVII-XVIII века); VI этап (обновление католицизма) начинается в 1891 году, в связи с выходом в свет энциклики Льва XIII «Rerum novarum» и длится до II Ватиканского; VII этап начинается в 60-х годах XX века (II Ватиканский собор) и длится по сей день” (П дЕ ЛоБьЕ, Три града. Социальное учение христианства, пер. Турчинского Л.А., вступ. ст. С. Аверинцева, СанктПетербург 2000, http://lliaooudd-filluel.bm3f.net.ua (дост. 22.09.2014) - tyt. oryg.: La pen-
} 
często korzystała ze wskazówek filozofii, co zapoczątkowało teologię pracy, kultury, polityki.

Podstawowa różnica w ocenie współczesnego ładu światowego między Watykanem i RCP polega na dostrzeganiu źródeł zagrożeń przez Rzym w sferze ekonomicznej, przez Moskwę zaś w sferze kulturowej i antropologicznej. Generalnie wizerunek globalizacji, szczególnie w ocenie Benedykta XVI, jest bardziej optymistyczny niż wizja RPC.

Interesującym aspektem podejścia do zagadnienia globalizacji przez RPC jest położenie nacisku na współpracę z państwem. Chociaż w oficjalnym stanowisku Cerkwi nie ma nawiązania do tradycji bizantyjskiej symfonii, to inne wypowiedzi wywodzą swój pozytywny antyglobalizacyjny program właśnie z tej tradycji. Państwo w poglądach rosyjskich współczesnych prawosławnych myślicieli koncentrujących się na problematyce globalizacji stoi w centrum uwagi. Tradycyjnie, obok prawosławia, jest ono najważniejszym elementem identyfikacji tożsamościowej, a w procesie globalizacyjnym według większości opinii ulega degradacji.

Aleksy Charin, historyk i politolog Rosyjskiej Akademii Służby Państwowej przy Prezydencie FR, przeprowadza analizę ewolucji współczesnego państwa. Wyodrębnia cztery podstawowe warianty: państwo-korporację, państwo-region, państwo-imperium i państwo-cywilizację ${ }^{9}$. Państwo-korporację opisał dokładnie A. Panarin ${ }^{10}$. M. Hardt i A. Negri ${ }^{11}$ wysunęli koncepcję współczesnego imperium, pozbawionego ośrodka władzy i określonego terytorium, zarządzanego przez aparat władzy, który globalnie poszerza swoje prerogatywy i granice. Stanowi strukturę sieciową obecną we wszystkich regionach świata. Głównymi obszarami tego imperium i centrami dowodzenia są USA, Unia Europejska i Chiny. Imperium odrzuca możliwość odwołania się do obecności sacrum w historii jako czynnika spajającego. Uważa, że misja tego imperium jest bardziej uniwersalna, globalna. Charin zadaje retoryczne pytanie: jakie wartości pretendują do miana uniwersalnych, jednoczących wszystkie narody, państwa w tym kosmopolitycznym imperium?

Według niego przeciwieństwem współczesnego imperium jest państwo-cywilizacja, którego istotę określają wartości religijne, specyficzne formy zacho-

sée sociale de l'Église catholique de Léon XIII à nos jours, Fribourg : Éditions universitaires Fribourg 1980).

${ }^{9}$ А. ХАРин, Эволюциионные модели государства постмодерна, http://svom.info/entry/301evolyucionnye-modeli-gosudarstva-postmoderna (dostęp: 21.10.2015)

${ }^{10}$ А. ПАНАРИН, Искушение глобализмом, Москва 2003, с. 122; TENŻE, Стратегическая нестабильность в ХХІ веке, Москва 2003, с. 182.

${ }^{11}$ M. HARDT, A. Negri, Imperium, przeł. S. Ślusarski, A. Kołbaniuk, Warszawa 2005, s. 46-54. 
wania ludzi oraz stosunek do innych państw i narodów. Autor wymienia tu cywilizację islamską i indo-buddyjską, których nie można oddzielić od czynnika religijnego. Specyfiką tego rodzaju organizmów jest to, że państwa jednoczą się nie według kryteriów politycznych (umów, porozumień, sojuszy), lecz religijnych. Procesy globalizacyjne prowokują dobitne stawianie pytań o znaczenie tożsamości kulturowej, ponieważ nie tylko kapitał się rozprzestrzenia ale także ,idee, symbole i sensy”. Charin jest zdania, że dla Rosji perspektywiczny jest wariant cywilizacyjny. Wymienia następujące przyczyny:

1. państwo-cywilizacja stanowi przeciwieństwo państwa-korporacji opartego na wartościach ekonomicznych, rynkowych. System wartości zakorzenionych w cywilizacji może zahamować degradację społeczeństwa, zjednoczyć je, wskazać wektory rozwoju;

2. układanie stosunków z innymi państwami i narodami na podstawie priorytetu ekonomicznego jest ułomne i nie ma głębszego uzasadnienia, muszą one opierać się na wspólnym systemie wartości. Uważa, że na razie dialog Rosji z Zachodem na podstawie wspólnych wartości jest możliwy;

3. Rosja powinna stworzyć państwo-cywilizację z tymi państwami, które tworzą kulturę opartą na tych samych wartościach. Zniknie wówczas problem narodu podzielonego;

4. podjęcie decyzji odnośnie do perspektyw Rosji jest problemem palącym, gdyż musi ona dokonać wyboru: albo zachować swoją odrębność (wolność), nie tylko w sensie ekonomiczno-gospodarczym, ale także społeczno-kulturowym, albo zejść ze sceny historii.

Andriej Okara ${ }^{12}$ zarysowuje podobne perspektywy dla Rosji. Dla niego wyznacznikiem wspólnoty jest prawosławie, dlatego cywilizację definiuje nieco inaczej niż Charin. Nazywa ją postbizantyjską wspólnotą narodów, nawiązując do tytułu książki emigracyjnego historyka sera Dymitra Oboleńskiego (Византийское содружество наиий). Mimo różnic terminologicznych ich poglądy są zbieżne. Okara pisze o wspólnocie prawosławnej opartej na wartościach egzystencjalnych, religijnych i historiozoficznych ${ }^{13}$. Jest zdania, że dla samoidentyfikacji Rosji, Ukrainy i Białorusi kluczowe jest wyzwanie stawiane przez Zachód. Cywilizacja jako przestrzeń bardziej różnorodna i pojemna, jak

\footnotetext{
${ }^{12}$ Politolog, obywatel RF narodowości ukraińskiej, w przeszłości dyrektor Centrum studiów wschodnioeuropejskich (obronił doktorat nt.: Idee prawno-polityczne konserwatyzmu rosyjskiego w XX w., narodowości ukraińskiej).

${ }^{13}$ А. ОКАРА, В окрестностях нового Константинополя. Восточнохристианская ичивилизация перед лииом новейшего мирового хаосопорядка, „Свободная мысль” 2012, nr 1-2, Май, s. 157-172.
} 
ją postrzega Okara, może zawierać w postaci komponentu bardziej zwartą, składającą się z narodów i państw pokrewnych kulturowo i historycznie, przestrzeń. Tę szerszą, cywilizacyjną, przestrzeń mogą stanowić państwa i narody limitroficzne, z którymi Rosja winna nawiązać ściślejsze sojusze. Dla obszaru prawosławnej kultury są to: Polska, Czechy, Słowacja, Chorwacja, Kazachstan. Rosja bowiem ma wypracowane strategie współpracy ze Słowianami - katolikami i muzułmanami. Zasadniczy problem polega na tym, w jaki sposób własną religijną tożsamość uczynić narzędziem konsolidacji, wzajemnego zrozumienia i dialogu, a nie konfliktu. Podobne zadanie stoi przed Ukrainą, która nie powinna skonfliktować się z Polską i Tatarami Krymskimi, przed Serbią w stosunkach z Chorwacją oraz Bośnią i Hercegowiną, Grecją i Bułgarią w odniesieniu do Turcji.

Problem polega na tym, że nastąpiła demodernizacja i archaizacja tych państw pod przykrywką postmodernizmu (o takiej roli postmodernizmu jako ideologii i metodzie destrukcji pisał Panarin). W związku z tym w czasach burzenia starego ładu politycznego w świecie powstała potrzeba szukania alternatywnych form społecznego rozwoju. Współczesna socjologia proponuje światu nie-zachodniemu trzy możliwości odpowiedzi na wyzwanie płynące z Zachodu:

1. westernizację, neomodernizację, transformację $\mathrm{w}$ ramach zachodniego modelu rozwoju;

2. postmodernizację jako rozwój na bazie własnej tożsamości;

3. połączenie modelu tradycyjnego $\mathrm{z}$ westernistycznym.

Ten ostatni wariant, według autora, nie ma szans na powodzenie, ponieważ przeszkodą są tu odmienne narzędzia: polityczne, ekonomiczne i kognitywne. Podaje przykłady destrukcyjnych efektów próby połączenia modeli: upadek poziomu edukacji po wprowadzeniu systemu bolońskiego (egzaminy testowe), zachodni, hedonistyczny model kultury masowej i rozrywkowego stylu życia bez podbudowania ich etyką pracy; system grantowy, który wymusza standardy naukowe zwłaszcza w naukach humanistycznych i społecznych, wprowadzając w ich obręb „zakażone teorie”; narzucanie przy pomocy środowisk lobbystycznych i technologii informacyjnych określonego schematu modernizacji, czemu towarzyszą duże pożyczki udzielane na określonych warunkach.

Odpowiedzi na wyzwanie Zachodu, zdaniem autora, można jedynie udzielić, łącząc podejście operacyjne $\mathrm{z}$ aksjologicznym. Podejście aksjologiczne oznacza, że współcześnie nie wystarcza dobra odpowiedź na wyzwanie Zachodu, lecz rzucenie własnego wyzwania o znaczeniu globalnym. Okara twierdzi, że 
kultura wschodniochrześcijańska ma potencjał, który może posłużyć jako innowacyjny w tworzeniu projektów transformacji społecznej i politycznej.

$\mathrm{Na}$ pierwszym miejscu wymienia prawosławną antropologię, jako fundament ustroju społecznego. Podkreśla, że podstawowe różnice między kulturami wschodnio- i zachodniochrześcijańską mają swoje źródło w antropologii: rozumieniu sensu życia i śmierci, grzechu, zbawienia, przemienienia, w rozumieniu pracy i przygotowania do pośmiertnej egzystencji. Z nich wynika odmienność w postrzeganiu Kościoła, społeczeństwa, państwa i świata. W tym kontekście mowa jest o roli energii Bożych w obcowaniu stworzenia ze Stwórcą, hesychasmu, o możliwości przezwyciężenia ograniczeń codzienności, o realności doświadczenia transcendencji. Człowiek postrzegany jest w perspektywie transcendentnej, eschatologicznej, wykraczającej poza granice ontologii. Okara zauważa że, choć sekularyzacja od wieku XVIII pomniejszała znaczenie prawosławnego rozumienia człowieka, to ten model antropologiczny zakorzenił się w kulturze, zwłaszcza w literaturze.

W kulturze zachodnioeuropejskiej człowiek umieszczony jest w ograniczonych ramach antropologii, skoncentrowany na dążeniu do zadośćuczynienia i zbawienia, rozumianych jako ziemskie zadanie. Obca mu jest wartość przebóstwienia. W głównym nurcie kultury Zachodu przeważa minimalistyczny ideał człowieka (минимальный человек, юридический, экономический, физиологический, hoто iuridicus, оесопотісиs, physiologicus) - w kontekście prawa, ekonomii, fizjologii. Dawny zochodniochrześcijański ideał człowieka przeżywa kryzys. Cywilizacja zachodnia jest w stanie generować nowe technologie, ale wyczerpała swój potencjał w dziedzinie odkrywania nowych sensów ludzkiego istnienia. $\mathrm{Z}$ tego powodu maksymalistyczna antropologia prawosławna może stanowić niezbędną wartość w budowaniu nowego humanizmu o znaczeniu uniwersalnym, w odnowieniu i uduchowieniu świata.

Okara twierdzi, że cywilizacja prawosławna może z korzyścią dla siebie zastosować tzw. soft power - zdolność państwa do pozyskiwania sojuszników i zdobywania wpływów dzięki atrakcyjności własnej kultury, polityki i ideologii państwowej. Twórca tego pojęcia, Joseph Nye, pisze: „Jeśli przywódca reprezentuje wartości, za którymi inni chcą podążać, rządzenie mniej kosztuje"14. Okara definiuje wschodniochrześcijańską soft power jako atrakcyjny światopogląd, zbudowany na wartościach kulturowych i politycznych, oraz możli-

\footnotetext{
${ }^{14}$ J. Ney, Soft power - za: A. SŁodownik, Amerykanin na dachu świata, „Dutygodnik.com" 2010, nr 21, http://www.dwutygodnik.com/artykul/778-soft-power-subtelnie-i-sku tecznie.html (dostęp: 10.01.2015).
} 
wości kreowania polityki zagranicznej za pomocą tych pozytywnych wzorców. To jednak jest trudne w sytuacji, kiedy proces ten chce uruchomić wspólnota państw, ponieważ ich potencjałów nie można arytmetycznie zsumować. Efektem może być rezonans, co obserwujemy w przypadku działania Zachodu, lub rozproszenie własnego potencjału.

Problem Rosji, Ukrainy, Grecji i innych państw polega na tym, że, mimo posiadania arsenału soft power użycie go nie było nigdy brane pod uwagę przez elity tych państw ani na poziomie koncepcji, ani praktyki. Subiektywny rozwój tych państw w ciągu wielu wieków stanowi przeszkodę we współpracy. W Imperium Rosyjskim i Związku Radzieckim pierwszorzędną rolę odgrywała zaś tożsamość imperialna, należy dodać - za wyjątkiem planów wyzwolenia Konstantynopola.

W okresie postradzieckim państwa prawosławne nie postrzegają siebie jako generatorów projektów geopolitycznych i geokulturowych (wyjątkiem solidarność w obronie Kosowa), nie wytworzyła się wspólna polityczna retoryka, państwa te nie przejawiają cywilizacyjnej solidarności i chęci współpracy. W przestrzeni postradzieckiej nagromadziły się natomiast antagonizmy między: Rosją, Ukrainą, Gruzją i Mołdawią. Nadal powraca się do symboliki i wartości radzieckich bądź zachodnich. Kontekst ten sprawia, że na pierwszy rzut oka wzorzec cywilizacji wschodniochrześcijańskiej wydaje się mało żywotny, samowystarczalny i skazany na marginalizację.

Jako atuty cywilizacji prawosławnej autor wymienia też: prawosławną naukę społeczną oraz symfonię władzy jako ważną tożsamościową wartość.

Okara dostrzega realne przeszkody związane z globalizacją. Globalizacja skomplikowała systemy zarządzania, pojawiły się nowe podmioty polityczne, społeczności wirtualne, subkultury, technologie kontrolowanego chaosu, asymetrycznych strategii (wojny stały się zjawiskiem komercyjnym i sprywatyzowanym - są zarówno źródłem dochodu dla tzw. war lordów, jak i pożywką dla mediów; wojny dzisiejszych czasów mają wymiar asymetryczny, tj. spory toczą się między dwoma nierównymi przeciwnikami i jednocześnie nie dają się zamknąć w ustanowione normy prawa międzynarodowego), proliferacja (zjawisko przemytu, transferu, rozprzestrzeniania broni masowego rażenia); z tego powodu mówi się o tzw. przyszłości otwartej, w odróżnieniu od modernistycznej zamkniętej - przewidywalnej. Horyzont prognozowania zawęża się. Dlatego powodzenie opisywanego projektu dostrzega w stworzeniu gospodarczego i politycznego bloku wymienionych państw, w kreatywności i ambicjach młodego pokolenia. 
Autor kończy pesymistycznym wnioskiem, że dziś żadne z branych przez niego pod uwagę państw, nawet Rosja, nie są gotowe do realizacji tego zadania:

Не только интегрированные в западные структуры Греция, Кипр, Болгария и Румыния, не только взявшие курс на подобную интеграцию Украина, Грузия, Черногория, Сербия, но даже Россия, Беларусь, Армения и Молдавия ${ }^{15}$.

Proponuje zatem program pozytywistyczny: tworzenie porozumień dwustronnych, pobudzanie świadomości tożsamościowej w społeczeństwach, rozwijanie nauk humanistycznych, przechodzenie od teorii ku praktyce.

Druga poważna przeszkoda to koegzystencja Rosji z Zachodem na zasadzie: wyzwanie Zachodu - odpowiedź Rosji świadczy, zdaniem Okary, o niedorozwoju podmiotowości tej ostatniej. Jednak dzisiejszy stan globalnego chaosu stwarza okazję do wydźwignięcia na poziom uniwersalny prawosławnej cywilizacji dzięki nośności jej wartości. Może być motywowane nie tylko racjonalnością ale opatrznością, współpracą na poziomie tworzenia sensów (znaczeń), potrzebą budowania nowej jakości, a nie ciągłej reakcji na wyzwanie Zachodu.

Charakterystyczny i zarazem zaskakujący jest fakt, że żadna z powyższych refleksji autora, ani żaden z wniosków nie przetrwał próby doświadczeń Majdanu, Krymu i Donbasu. Liczne wypowiedzi Okary na łamach: prasy, bloga, radia czy telewizji mają czysto publicystyczny, doraźny i polemiczny charakter $^{16}$. Choć w czerwcu 2012 r. pisał:

Оба пути - и „малороссийство”, и „государство-нация” - фактически являются выражением политического и духовного минимализма национальной элиты: она смиряется с собственной ролью ведомой, но не ведущей силы, она понимает Ук-

\footnotetext{
${ }^{15}$ А. ОКАРА, В окрестностях нового Константинополя.

${ }^{16}$ Oto próbka wypowiedzi z września 2014 r.: „На одной стороне сражаются, в основном, военные, исповедующие восточное христианство. Причем, поскольку многие из них из Западной Украины, христианство для них - не пустой звук и не только красивый обряд. На другой - огромное количество людей, исповедующих некие квази-религиозные полуязыческие культы, и людей с откровенно сектантским типом сознания. С уничтоженной рациональностью, с мышлением, неспособным к осознанию простейших причинно-следственных связей, с ватообразными мозгами. И с верой - но не в Христа, а в Православие, в доктрину «политического православия», в Святую Русь, в Русскій Міръ, в Тысячелетнюю Империю, в СССР-2, в Новороссию, в американский заговор, в то, что на киевском Майдане людей кормили печеньем с наркотой и проч., и проч. Но Христос им почему-то неинтересен” (А. ОКАРА, „Священная” война в Донбассе, «Новое время» 4 сентября, 2014, http://nvua.net/opinion/okara (dostęp: 10.01.2015)).
} 
раину как объект, но не субъект международных отношений (вне зависимости от идеологических самовнушений и пропаганды)....Но если до 1991 года роль „младшего брата" Украине навязывала Россия, то теперь подобная субординация (правда, в отношении Запада) является результатом свободного выбора национальной политической элиты, разучившейся мыслить в иных категориях. (Так, например, влиятельный украинский политик Дмитрий Табачник, комментируя результаты визита Владимира Путина на Украину в апреле 2000 года, в интервью газете “День” заявил буквально следующее: "Украина имеет только один путь быстрыми, семимильными шагами двигаться в Европу. Откинув флер повышенного “политического целомудрия”, необходимо “отдаваться” Европе или “большой семерке").

В подобной перспективе Украину с Европой будет разделять такая своего рода “мембранная" граница: с одной стороны, на Украину распространится крайне невыгодный для украинской же промышленности ценовой режим на энергоносители, полностью откроются украинские рынки сбыта, резко возрастет внешняя экспортная интервенция и т.д. С другой стороны, украинское присутствие в Европе будет тщательно минимизировано самой же Европой. Получим самое что ни на есть “открытое общество" - полностью проницаемое для внешних субъектов управления, - как и учил великий Сорос! Но собственное влияние такого государства и общества, если оно окончательно не парализуется, будет ограничено собственными же границами. Думаю, что разговоры об украинском суверенитете в этом случае полностью превратятся в фигуру речи"17.

Obecnie Okara wypowiada się w stylu rzecznika prezydenta Poroszenki, w najmniejszym stopniu nie nawiązuje do swoich wcześniejszych analiz, naukowych interpretacji czy nawet publicystyki.

Trzecim wybranym przeze mnie krytykiem globalizmu jest archimandryta Olimpiusz (Kastalski) dyrektor Patriarszego Wydawnictwa Ławry Troickiej, autor podręcznika teologii dogmatycznej. Podczas obrad VII Plenum Synodalnej Komisji Teologicznej w 2001 r. wygłosił referat Globalizacja jako instrument apostazji (Глобализация как инструмент апостасии), wnoszący nowe spojrzenie na omawiany problem ${ }^{18}$. Zaprzecza on poglądowi, jakoby globalizacja ze swymi negatywnymi tendencjami była zjawiskiem determinującym przyszłość świata. Globalizacja jest, jego zdaniem, owocem ludzkiej wolności, która zrodziła niespotykaną dyktaturę pustki. Przez zło, jakie niesie, rozbudza ludzkie sumienia. To zło dzięki globalizacji stało się naoczne, jawne. Zglobalizowany świat może stać się przestrzenią misji.

${ }^{17}$ А. ОКАРА, В поисках имперской перспективы, травня 29, 2012, http://www.mesoeurasia. org/archives/9420, (dostęp: 10.01.2015).

${ }^{18}$ АРХИМАНДРИт АЛИПИЙ (КАСТАЛЬСКИЙ-БОРОЗдИН), Глобализация как инструмент anocmaсии, http://apokalypsis.ru/problemy-sovremennoj-eskhatologii (dostęp: 10.01.2015). 
Globalizacja sprawiła, że niepomiernie wzrosła wiedza o świecie. Ale ma ona charakter fragmentaryczny, służy celom woluntarystycznym, zarządzaniu i manipulacji. Sprawia, że człowiek staje się ofiarą swojej wolności i władzy nad światem. Globalizacja jest środowiskiem zbudowanym przez człowieka, które zapełnia sam sobą, jest to świat uczłowieczony przez starego Adama, dlatego można go nazwać odczłowieczonym, ponieważ człowiek, zdobywając wszechświat, władając tajemnicą życia, psychiki, materii, staje się wrogiem swojego prawdziwego - przebóstwionego - człowieczeństwa.

Współczesna globalizacja w porównaniu z dwiema poprzednimi uczy, że człowiekiem jest o wiele łatwiej sterować za jego zgodą, gdy sam przejawia pożądaną aktywność, bez przymusu, w więzieniu bez krat. Jej cele archimandryta określa w następujący sposób:

1. создание единой универсальной религии на базе традиционных вероисповеданий;

2. создание единой сверхкультуры на основе разрушенных самобытных культур: европейской, американской, исламской, восточных и др.;

3. создание единой цивилизации без деления на государства;

4. создание единого планетарного этноса путем ассимиляции всех существующих народов;

5. создание единой торгово-финансовой системы через поглощение экономик независимых государств. Организация глобального компьютерного учета людей и товаров.

Olimpiusz dostrzega, że współczesne chrześcijaństwo zachodnie coraz bardziej kategorycznie akcentuje człowieczeństwo Wcielenia, stąd nacisk na etykę i stosunki międzyludzkie. Wschód dostrzega Bożą tajemnicę w człowieku i świecie, dlatego globalizacja może być rozumiana jako dopust Boży. Każdy grzech i zbłądzenie mogą zostać odczytane jednocześnie jako wyzwanie i wezwanie. Zapomnienie, do którego wzywa globalizacja, przywołuje Pamięć, standaryzacja ludzkiego wyglądu rodzi tęsknotę za ikoną, choroba samotności, porażająca całe społeczeństwa, które zamieniły się w zbiorowiska jednostek, domaga się uzdrowienia poprzez soborowość.

Olimpiusz zwraca też uwagę na te wypowiedzi zachodnich ośrodków decyzyjnych, które w kontekście globalizacji odnoszą się do Rosji. Przytoczmy wypowiedź premiera Johna Majora:

Задача России... - обеспечить ресурсами благополучные страны. Но для этого им нужно всего пятьдесят-шестьдесят миллионов человек ${ }^{19}$.

\footnotetext{
19 „Российская Федерация сегодня” 2000, nr 22, s. 28.
} 
Archimandryta dostrzega dla Rosji jedno wyjście z tej sytuacji, zaproponowane przez wysokiego urzędnika państwowego A. Ignatowa: «Если нельзя бороться с движением, следует его возглавить» ${ }^{20}$.

W interpretacji Olimpiusza najpełniej odzwierciedlona została eschatologiczna, uniwersalna perspektywa spojrzenia na zjawisko globalizacji. Charin i Okara posługują się tą perspektywą, ale służy im ona do dowartościowania projektu o charakterze politycznym. Eschatologia, pojęcie semantycznie szersze niż historia, kultura, cywilizacja, a nawet człowiek, pełni w ich koncepcjach rolę służebną, jest domyślnym komponentem tradycji kultury prawosławnej.

Interpretacja archimandryty Olimpiusza koresponduje z passusem zawartym w książce Hardta i Negri ${ }^{21}$. Dowodzą oni, że globalizacja jest konsekwencją rozwoju europejskiej nowoczesności, która, począwszy od XIII w., odrzuciła Bożą transcendentną władzę nad sprawami świata, zaczęła odkrywać sferę immanencji: „, Ludzkość zawłaszczyła na powrót to, co odebrała jej średniowieczna transcendencja" ( s. 89). Odrzucenie transcendencji jest tym samym co powrót do egzystencji starego Adama, jest to ucieczka od transcendencji w egzystencję, wymusza redefinicję ontologii wartości. Jeszcze jedna uwaga zawarta $\mathrm{w}$ tej książce trafnie dookreśla problem, o którym mowa. Autorzy twierdzą, że ontologiczny dualizm kultury średniowiecza musiał zostać zastąpiony dualizmem funkcjonalnym, posługującym się mechanizmem zapośredniczenia. Niemożliwa już jest bezpośrednia relacja między człowiekiem a Bogiem i naturą, lecz za pośrednictwem ukonstytuowanego porządku, np. przyroda przez filtr zjawisk, Bóg przez filtr rozumu. Autorzy nazywają to aparatem dyscyplinującym rzeszę wolnych podmiotów. Odtąd myśl, aby ludzie mogli bezpośrednio ustanowić swoją wolność w byciu, postrzegana była jako wywrotowa (s. 94-95). Pojęcie transcendentności przeniesiono na takie zjawiska, jak: rozum, aparat polityczny, który rzesze przekształca w uporządkowaną całość. Transcendencja myślenia o człowieku doprowadziła do konstatacji, że jeśli myśleć o nim jako o czymś odrębnym od natury, to on nie istnieje. Tak zakończyło się przeniesienie transcendencji Boga na człowieka (s. 107).

Istnieje podstawowa zbieżność między sposobem myślenia i interpretacji rosyjskich autorów oraz Hardta i Negri. Omawiane zjawiska ukazane są w przestrzeni, nie w perspektywie czasowej, ważna jest ich ontologia, nie ewolucja. Dlatego w ich interpretacji, choć globalizacja ma swoje cechy historyczne, to jej ontologia jest czymś od wieków niezmiennym.

\footnotetext{
${ }^{20}$ Tamże.

${ }^{21}$ M. HARdt, A. NeGRI, Imperium.
} 


\section{GLOBALIZACJA W ROSYJSKIEJ MYŚLI PRAWOSŁAWNEJ}

\section{Streszczenie}

W łonie chrześcijaństwa możemy zauważyć różne podejścia do problemu globalizacji. Podstawowa różnica w ocenie współczesnego ładu światowego między Watykanem i RCP polega na dostrzeganiu źródeł zagrożeń przez Rzym w sferze ekonomicznej, przez Moskwę zaś w sferze kulturowej i antropologicznej. RPC kładzie nacisk na współpracę z państwem. Tradycyjnie, obok prawosławia, jest ono najważniejszym elementem identyfikacji tożsamościowej.

Aleksy Charin, historyk i politolog, zauważa, że przeciwieństwem współczesnego imperium jest państwo-cywilizacja, którego istotę określają wartości religijne. Dla Rosji perspektywiczny jest wariant cywilizacyjny. Inny politolog - Andriej Okara - jest zdania, że dla samoidentyfikacji Rosji, Ukrainy i Białorusi kluczowe jest wyzwanie stawiane przez Zachód._Podkreśla, że podstawowe różnice między kulturami wschodnio- i zachodniochrześcijańską mają swoje źródło w antropologii: rozumieniu sensu życia i śmierci. Archimandryta Olimpiusz (Kastalski) zauważa pozytywne strony globalizacji. Zapomnienie, do którego wzywa globalizacja - przywołuje Pamięć, standaryzacja ludzkiego wyglądu rodzi tęsknotę za ikoną. Omawiane zjawiska ukazane są przez rosyjskich myślicieli w przestrzeni nie w perspektywie czasowej, ważna jest ich ontologia, nie ewolucja. Dlatego globalizacja w ich interpretacji, choć ma swoje cechy historyczne, to jej ontologia jest czymś od wieków niezmiennym.

\section{РУССКИЕ ПРАВОСЛАВНЫЕ МЫСЛИТЕЛИ \\ О ПРОБЛЕМЕ ГЛОБАЛИЗАЦИИ}

\section{Р е $з$ ю м е}

Христианские Церкви по-разному относятся к глобализации. Основная разница в оценке современного мирового порядка между Ватиканом и Русской Православной Церковью (далее РПЦ) состоит в том, что Рим усматривает опасность в экономической сфере, Москва - в культурной и антропологической. Для РПЦ очень важно сотрудничество Цекви и государства. Согласно традиции, кроме православия, государство является наиболее важным элементом идентификации.

Алексий Харин - историк и политолог - отмечает, что современной империи можно противопоставить государство-цивилизацию, основой которого являются религиозные ценности. Для России перспективен цивилизационный вариант. Другой политолог - Андрей Окара - убеждает, что для самоидентификации России, Украины и Белоруси ключевым является вызов Запада. Подчеркивает, что основная разница между культурами восточно- и западно-христианской относится к антропологии: понимании смысла жизни и смерти.

Архимандрит Алимпий (Кастальский) замечает положительные стороны глобализации. Забвение, к которому ведет глобализация, призывает память, стандаризация человечесого облика порождает тоску по иконе. 
Вышеуказанные явления рассматриваются русскими мыслителями в пространственной, не во временной перспективе, важна их онтология, не эволюция. Поэтому глобализация в их интерпретации, хотя имеет исторические признаки, то ее онтология не меняется веками.

\section{GLOBALIZATION IN THE RUSSIAN ORTHODOX THOUGHT}

\section{S u m m a r y}

Relationship the Roman Catholic Church to the globalization is different than Russian Church. Rome can see threatening in the economic, Moscow in cultural and anthropological sphere. For the Russian church is important a cooperation with the government. Government and the Orthodox are two factors of the identification of Russian. Historian Aleksy Harin ar confronting the civilization with the empire. He is identifying the civilization with values. Political scientist Andrej Okara claims that Russia identifiction itself through the confrontation with the West. The Eastern culture is different than eastern in understanding the meaning of the life and death. Olympius prior (Kastalski) notices positive sides of the globalization. The oblivion characteristic of the globalization is summoning the memory, the standardization of the human appearance is giving rise to longing for the icon.

Defects in the globalization are shown by Russian thinkers in the space not in the time, their ontology is important, not an evolution. Therefore globalization which has historical features, however for her ontology is from time immemorial unchanging.

Słowa kluczowe: globalizacja, Cerkiew, państwo, kultura, człowiek.

Ключевые слова: глобализация, Церковь, государство, культура, человек.

Key words: globalization, church, state, culture, man. 